\title{
Evaluating Parents' Fear and Anxiety Towards Children Undergoing Chair Side and General Anesthesia Treatment Procedures - A Survey
}

\author{
Keerthana Baskar ${ }^{1}$ and Mebin George Mathew ${ }^{2}$ \\ ${ }^{1}$ Saveetha Dental College and Hospitals, Saveetha Institute of Medical and Technical Sciences(SIMATS), \\ Saveetha University, Chennai, India \\ ${ }^{2}$ Senior Lecturer, Department of Pediatric and Preventive Dentistry, Saveetha Dental College and Hospitals, \\ Saveetha Institute of Medical and Technical Sciences(SIMATS), Saveetha University, Chennai,India
}

\section{ABSTRACT}

The anxiety levels of parents is usually greater in children undergoing dental procedure due to the invasive procedures. General anaesthesia is generally advised in case of extensive dental decay or subsequent referral to general anaesthetic extraction. Parents usually feel that when their child is on GA, the procedure is more invasive and life threatening to that of the chair side procedure. This study is conducted to assess the anxiety of parents when their child undergoes a local anaesthetic procedure and a GA procedure. A simple closed ended questionnaire was provided to the parents of patients in the Pedodontics Department of Saveetha Dental College. A sample size of 50 was chosen. 80\% of the parents preferred local anaesthesia to general anaesthesia. Within the limitations of the study it was found that the majority of the parents preferred local anesthesia and preferred general anesthesia only under given conditions, such as in case of trauma or minor surgery.

KEY WORDS: GENERAL ANAESTHESIA, LOCAL ANAESTHESIA, CHILDREN, DENTAL TREATMENT, FEAR.

\section{INTRODUCTION}

Operative procedures in dentistry are controlled with the use of anaesthesia to a large extent (Haas, 2002). Anaesthesia are drugs that produce reversible loss of sensation. Dentists are professionals who use anaesthesia due to the invasive dental procedures done. Children are prone to dental caries and experience pain. Dentists, to overcome this pain during dental procedures inject anaesthesia so that the procedure can be done without

\section{ARTICLE INFORMATION}

*Corresponding Author: mebingeorgem.sdc@saveetha.com Received 2nd Aug 2020 Accepted after revision 25th Sep 2020 Print ISSN: 0974-6455 Online ISSN: 2321-4007 CODEN: BBRCBA

Thomson Reuters ISI Web of Science Clarivate Analytics USA and Crossref Indexed Journal

\section{Clarivate
Analytics}

NAAS Journal Score 2020 (4.31) SJIF: 2020 (7.728)

A Society of Science and Nature Publication,

Bhopal India 2020. All rights reserved.

Online Contents Available at: http//www.bbrc.in/

Doi: http://dx.doi.org/10.21786/bbrc/13.8/159 any pain and the patient is co-operative as well. Dental caries, commonly known as tooth decay, is a bacterial breakdown of the tooth (Vellingiri and Gurunathan, 2015). The cavities may vary from yellow to black depending upon the amount of dentin being affected and the type of caries. In a study which was in rural India, it was found that Caries was high among children (Gangwar et al., 1990; Khera, Tewari and Chawla, 1996; Rao, Sequeira and Peter, 1999; Chatufale and Goyal, 2002; Mathew and Soni, 2019). It was also found that the age group 8 to 10 years showed higher caries than age group 6 to 7 years. Poor oral health, particularly in children with chronic illness, can prove to be a risk factor for severe, even life threatening complications.

Good oral hygiene is utmost important for efficient mastication, aesthetics and for speaking ((Mathew, Roopa, et al., 2020; Mathew, Samuel, et al., 2020). If the caries is not treated at an earlier stage then it subsequently leads to the loss of tooth structure, pain and infection

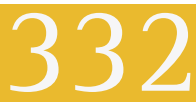


leading to invasive procedures (Foster and Fitzgerald, 2005). If the caries is left untreated due to negligence, it may eventually result in aggravated problems such as pain, suffering, odontogenic infection, early loss of teeth and space loss that might later on require more invasive, extensive and expensive treatments (Low, Tan and Schwartz, 1999; Thomas and Primosch, 2002; Anderson, Drummond and Thomson, 2004; Ratnayake and Ekanayake, 2005; Nagaveni, Poornima and Bajaj, 2019; Mathew, Soni and Khan, 2020; Nagaveni, Poornima and Mathew, 2020). The stages for the development of dental fear occurs in children during childhood and adolescent years (Ost, 1987; Milgrom et al., 1988; Locker et al., 1999).

Therefore, it is important that children develop a positive attitude towards dentistry( (Neena et al., 2017; Mebin George Mathew, 2020). An objective of dental care is to lead children step-by-step through the provision of dental care. Dental care for children is usually carried out by the use of behavioural management techniques coupled with the use of local anaesthesia (Nagaveni, Yadav and Poornima, 2017). However, the various behaviour management techniques used must be tailored to the individual patient and practitioner. When techniques fail or when treatment needs are extensive, general anaesthesia or dental care in children is sometimes necessary to provide safe, and effective treatment( Mebin George Mathew, 2020; M. G. Mathew, 2020). General anaesthesia are agents which when administered induce various degrees of analgesia, depression of consciousness, circulation, and respiration; relaxation of skeletal muscle; reduction of reflex activity; and amnesia (Olsson and Hallén, 1988; Morita et al., 2001). General anaesthetics are of two types, namely inhalation and intravenous. From the previously conducted studies, it can be inferred that there is a higher pre-operative mortality rate in children compared with adults.

Local anaesthesia are the agents that block nerve conduction when administered locally to nerve tissue in appropriate concentrations. The drugs act on any part of the nervous system and also on every type of nerve fiber. When in contact with a nerve trunk, these agents can cause both sensory and motor paralysis in the innervated area. The action of local anaesthetic is completely reversible (Brunton, Chabner and Knollman, 2011). Adverse effects of local anaesthesia includesanaesthetic toxicity, postoperative soft tissue injury, allergic reactions, and paresthesia . Parents' opinion on the anaesthesia to be administered on their children and the reason for their preference is to be evaluated (Luong, 2010). Generally, local anaesthetic is only administered during a chair side procedure which is simple. But when there are complications or a lot of treatment needed to be done to a very young patient or a patient who is uncooperative, general anaesthesia is administered. The opinions of the parent of the patient is important as the parents are well aware and educated about the approaches in the medical field. Hence it is important to get the consent from the parent (Haas, 2002).
Our department is passionate about child care, we have published numerous high quality articles in this domain over the past 3 years (Govindaraju, Jeevanandan and Subramanian, 2017a, 2017b; Panchal, Gurunathan and Shanmugaavel, 2017; Ravikumar, Jeevanandan and Subramanian, 2017; Jeevanandan and Govindaraju, 2018; Nair et al., 2018; Ravikumar et al., 2018, 2019; Ravindra et al., 2018, 2019; Subramanyam et al., 2018; Vishnu Prasad et al., 2018; Jeevanandan, Ganesh and Arthilakshmi, 2019; Ramadurai et al., 2019; Ramakrishnan, Dhanalakshmi and Subramanian, 2019; Veerale Panchal, Jeevanandan and Subramanian, 2019; Vignesh et al., 2019; V. Panchal, Jeevanandan and Subramanian, 2019; Samuel, Acharya and Rao, 2020). With this inspiration we planned to pursue research on evaluation of the anxiety of parents while doing a clinical procedure under local anaesthetic and general anaesthetic.

\section{MATERIAL AND METHODS}

A simple questionnaire was prepared which was given to the parents of the children undergoing a dental treatment. The questionnaire was close ended with simple yes/ no answers. A sample size of 50 was taken. Parents of patients who had come to the Pedodontics Department of Saveetha Dental college were chosen. An informed consent was taken from these parents before taking part in the survey. The survey also had basic demographic detail of the participants.

\section{QUESTIONNAIRE:}

Parent's Name:

Gender:

Parent's contact number:

Age:

1. Kind of pain you expect your child to have while administered with general anaesthesia .

a) $\quad$ Mild

b) Moderate

c) Severe

d) No pain

2. Do you prefer general anaesthesia when the child is not co-operative

a) Yes

b) No

3. Does your child have fear of medical treatments

a) Yes

b) No

c) Don't know

4. Do you want the child not to cry during medical procedures?

a) Yes

b) No

5. I prefer general anaesthetic during trauma

a) Yes

b) No

6. Do you prefer administration of general anaesthesia/ local anaesthesia for the treatment?

7. Do you prefer general anaesthesia in case of minor surgery?

a) Yes 
b) No

8. After local anaesthesia, the kind of pain I expect my child will be having

a) Mild

b) Moderate

c) Severe

d) No pain at all

9. Expect my child to be drowsy

a) Yes

b) No

10. Expect my child to have sore throat

a) Yes

b) No

\section{RESULTS AND DISCUSSION}

Of the 50 parents who took the survey, it was found that 23 participants were males and 27 were females. 34\% of participants aged between 21-25 years were females, $18 \%$ of participants aged 26-30 years were males and $4 \%$ of participants in the age group of 31-35 years were females. (Figure 1) From this survey, it was found that $40 \%$ of the parents believed that there will be no pain induced to the child when given a general anaesthesia. $60 \%$ of the parents also preferred general anaesthesia when the child was not co-operative. About 20\% of the parents didn't know if their child fears treatment as it was the first dental visit of the child. It was also found that $60 \%$ of the parents agreed on the administration of general anaesthesia during trauma and 80\% preferred while undergoing minor surgery. It was found that $80 \%$ preferred local anaesthesia for dental procedures as it would cause much lesser side effects and also that the child will be co-operative under local anaesthesia. 20\% of the parents believe that their child will have moderate pain on administration of local anaesthetic. 50\% of the parents felt that their child would be drowsy after the administration of general anaesthesia and 60\% believed that their child will have sore throat. (Table 1)

Figure 1: Bar graph shows association between age and gender of participants who took up the survey. X-axis denotes age of participants and Y-axis denotes number of participants in each gender. It was found that females (blue) were more in the age group of 21-25 years and males (31-35 years) were more in the age group of 31-35 years. $P$ value is 0.337 , hence statistically not significant.

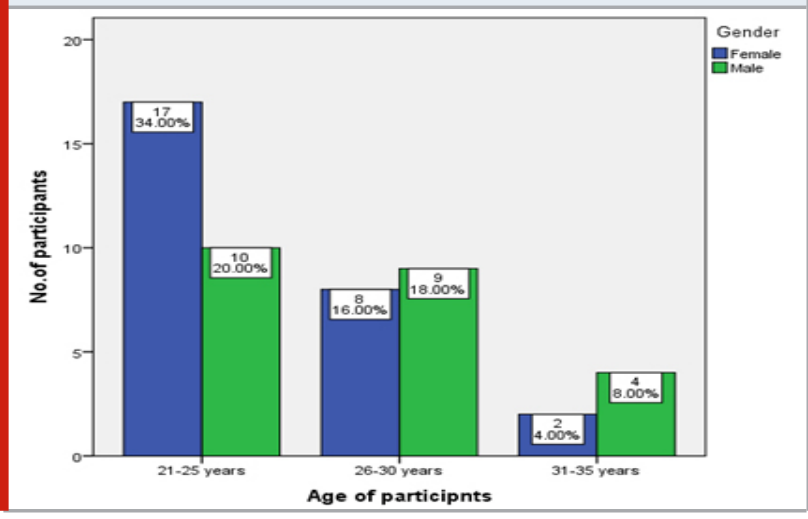

Table 1. Table showing the responses given by the participants to the questionnaire.

\begin{tabular}{|c|c|}
\hline Question & Results \\
\hline $\begin{array}{l}\text { 1. Kind of pain you expect your } \\
\text { child to have while administered } \\
\text { with general anaesthesia }\end{array}$ & $\begin{array}{c}\text { Mild - 30\% } \\
\text { Moderate-30\% } \\
\text { Severe- } \\
\text { No pain-40\% }\end{array}$ \\
\hline $\begin{array}{l}\text { 2. Do you prefer general } \\
\text { anaesthesia when the child is } \\
\text { not co-operative }\end{array}$ & $\begin{array}{l}\text { Yes-60\% } \\
\text { No-40\% }\end{array}$ \\
\hline $\begin{array}{l}\text { 3. Does your child have fear of } \\
\text { medical treatments } \\
\text { Don't know-20\% }\end{array}$ & $\begin{array}{l}\text { Yes-40\% } \\
\text { No-40\% }\end{array}$ \\
\hline $\begin{array}{l}\text { 4.Do you want the child not to cry } \\
\text { during medical procedures? }\end{array}$ & $\begin{array}{l}\text { Yes-50\% } \\
\text { No-50\% }\end{array}$ \\
\hline $\begin{array}{l}\text { 5. I prefer general anaesthetic } \\
\text { during trauma }\end{array}$ & $\begin{array}{l}\text { Yes-40\% } \\
\text { No-60\% }\end{array}$ \\
\hline $\begin{array}{l}\text { 6. Do you prefer administration } \\
\text { of general anaesthesia/ local } \\
\text { anaesthesia for the treatment? }\end{array}$ & $\begin{array}{c}\text { General } \\
\text { anaesthesia-20\% } \\
\text { Local anaesthesia } \\
-80 \%\end{array}$ \\
\hline $\begin{array}{l}\text { 7. Do you prefer general } \\
\text { anaesthesia in case of minor surgery? }\end{array}$ & $\begin{array}{l}\text { Yes-80\% } \\
\text { No-20\% }\end{array}$ \\
\hline $\begin{array}{l}\text { 8. After local anaesthesia, the kind of } \\
\text { pain I expect my child will be having }\end{array}$ & $\begin{array}{l}\text { Mild-40\% } \\
\text { Moderate-20\% } \\
\text { Severe-No } \\
\text { pain-40\% }\end{array}$ \\
\hline 9. Expect my child to be drowsy & $\begin{array}{l}\text { Yes-50\% } \\
\text { No- } 50 \%\end{array}$ \\
\hline $\begin{array}{l}\text { 10. Expect my child to have sore } \\
\text { throat }\end{array}$ & $\begin{array}{l}\text { Yes-40\% } \\
\text { No-60\% }\end{array}$ \\
\hline
\end{tabular}

Dental caries is common in children aged less than 6 years. It is a rapid and progressive disease that can be painful and increases the likelihood of poor child growth, development and social outcomes (Resine, 1985; Gift, Reisine and Larach, 1992; Hollister and Weintraub, 1993; Coté et al., 2000; Edelstein, 2000; Acs et al., 2001).[20-25 ] It has been found that by 5 years of age approximately $30 \%$ of children have had one or more teeth with dental decay, of which approximately 7\% of the children required urgent care, in Canadian surveys. In a study conducted by Sutharshana et al, it was found that 97\% of the parents preferred local anaesthesia over general anaesthesia for their child's dental treatment (Vellingiri and Gurunathan, 2015).

In a study conducted in 1992, statistics have been shown that 39\% of emergency dental visits were in the Dental Department of Montreal Children's Hospital were due to severe dental decay and 70\% of these visits were children in the age group of 1 to 5 years. The same age group contained $70 \%$ of the cases with toothaches and $48 \%$ of the cases with dental infections caused by dental caries in a study conducted by Schwartz (Schwartz, 1994). Surveys have found that 30\% of children have had dental caries 
in one or more teeth , and 7\% of these children required urgent treatment.

The satisfaction of parents plays a major role in the healthcare domain, With the growing awareness of the parents due to the availability and ease of accessibility of information It is important for the dental care professionals to understand that parents visit a dentist to get relief from the physical discomfort of their child's dental pain and to treat the obvious dental disease and therefore agree for the general anesthesia to carry out dental procedures.

The physicians indicated in a study that was conducted in 2008, that socioeconomic status and educational qualification of the patient did affect their clinical management decisions. Hence, physicians had to commonly make changes to their management plan in an effort to increase the efficiency of the treatment outcomes, but they experienced numerous strains when trying to balance what they believed was feasible for the patient with what they perceived as established standards of care (Bernheim et al., 2008). Thus, the socioeconomic status and educational qualification of the parents plays a major role in treatment decisions and outcome for their children's medical care.

A study conducted on parental educational and children's health shows a strong positive association between parental socioeconomic status and child health. In this study on parent's preference to general or local anesthesia, parent's socioeconomic status was also and most of the parents who participated in this study consisted of upper lower class and they preferred local anesthesia generally for the dental treatments and preferred general anesthesia only under specific conditions.

\section{CONCLUSION}

Within the limitations of the study it was found that the majority of the parents preferred local anesthesia and preferred general anesthesia only under given conditions, such as in case of trauma or minor surgery. The opinion of the parents can be altered according to the behaviour of the child, and irrespective of this, the procedure should be explained to the parent and other members of the healthcare team to prevent miscommunication and parental dissatisfaction. The ultimate goal of paternalistic dental treatment achieving positive behavior of the child and delivering safe and quality dental treatment.

\section{REFERENCES}

Acs, G. et al. (2001) 'Perceived outcomes and parental satisfaction following dental rehabilitation under general anesthesia', Pediatric dentistry, 23(5), pp. 419-423.

Anderson, H. K., Drummond, B. K. and Thomson, W. M. (2004) 'Changes in aspects of children's oralhealth-related quality of life following dental treatment under general anaesthesia', International Journal of Paediatric Dentistry, pp. 317-325. doi: 10.1111/j.1365- 263x.2004.00572.x.

Bernheim, S. M. et al. (2008) 'Influence of patients' socioeconomic status on clinical management decisions: a qualitative study', Annals of family medicine, 6(1), pp. 53-59.

Brunton, L., Chabner, B. A. and Knollman, B. (2011) Goodman and Gilman's The Pharmacological Basis of Therapeutics, Twelfth Edition. McGraw Hill Professional.

Chatufale, J. D. and Goyal, R. C. (2002) 'A CrossSectional Study of Factors Related to Oral Health In Rural Area of Loni, Western Maharashtra', Indian journal of community medicine: official publication of Indian Association of Preventive \& Social Medicine. Medknow Publications, 27(2), p. 74.

Coté, C. J. et al. (2000) 'Adverse sedation events in pediatrics: a critical incident analysis of contributing factors', Pediatrics, 105(4 Pt 1), pp. 805-814.

Edelstein, B. L. (2000) 'Dental pain in children: Its existence and consequences', JOURNAL-AMERICAN COLLEGE OF DENTISTS. AMERICAN COLLEGE OF DENTISTS, 67(3), pp. 4-7.

Foster, H. and Fitzgerald, J. (2005) 'Dental disease in children with chronic illness', Archives of disease in childhood, 90(7), pp. 703-708.

Gangwar, S. K. et al. (1990) 'Biosocial correlates of dental caries in rural area of Lucknow', Journal of the Indian Dental Association, 61(4), pp. 93-97.

Gift, H. C., Reisine, S. T. and Larach, D. C. (1992) 'The social impact of dental problems and visits', American journal of public health, 82(12), pp. 1663-1668.

Govindaraju, L., Jeevanandan, G. and Subramanian, E. M. G. (2017a) 'Comparison of quality of obturation and instrumentation time using hand files and two rotary file systems in primary molars: A single-blinded randomized controlled trial', European journal of dentistry, 11(3), pp. 376-379.

Govindaraju, L., Jeevanandan, G. and Subramanian, E. M. G. (2017b) 'Knowledge and practice of rotary instrumentation in primary teeth among indian dentists: A questionnaire survey', Journal of International Oral Health, 9(2), p. 45.

Haas, D. A. (2002) 'An update on local anesthetics in dentistry', Journal , 68(9), pp. 546-551.

Hollister, M. C. and Weintraub, J. A. (1993) 'The association of oral status with systemic health, quality of life, and economic productivity', Journal of dental education, 57(12), pp. 901-912.

Jeevanandan, G., Ganesh, S. and Arthilakshmi (2019) 'Kedo file system for root canal preparation in primary teeth', Indian journal of dental research: official publication of Indian Society for Dental Research, 30(4), pp. 622-624.

Jeevanandan, G. and Govindaraju, L. (2018) 'Clinical comparison of Kedo-S paediatric rotary files vs manual instrumentation for root canal preparation in primary molars: a double blinded randomised clinical trial', 
European archives of paediatric dentistry: official journal of the European Academy of Paediatric Dentistry, 19(4), pp. 273-278.

Khera, N., Tewari, A. and Chawla, H. S. (1996) 'Intercomparison of prevalence and severity of dental caries in urban and rural areas of northern India', Journal of the Indian Society of Pedodontics and Preventive Dentistry. Medknow Publications, 14(1), p. 19.

Locker, D. et al. (1999) 'Age of onset of dental anxiety', Journal of dental research, 78(3), pp. 790-796.

Low, W., Tan, S. and Schwartz, S. (1999) 'The effect of severe caries on the quality of life in young children', Pediatric dentistry, 21(6), pp. 325-326.

Luong, N. (2010) Assessment of Parental Satisfaction with Dental Treatment Under General Anaesthesia in Paediatric Dentistry. Available at: https://tspace.library. utoronto.ca/handle/1807/25777.

Mathew, M. G., Samuel, S. R., et al. (2020) 'Evaluation of adhesion of Streptococcus mutans, plaque accumulation on zirconia and stainless steel crowns, and surrounding gingival inflammation in primary molars: Randomized controlled trial', Clinical oral investigations. Springer, pp. 1-6.

Mathew, M. G., Roopa, K. B., et al. (2020) 'Evaluation of clinical success, parental and child satisfaction of stainless steel crowns and zirconia crowns in primary molars', Journal of Family Medicine and Primary Care. Wolters Kluwer--Medknow Publications, 9(3), p. 1418.

Mathew, M. G. (2020) 'Management of a pediatric patient with ataxia telangiectasia: Report of a rare case in which diagnostic radiographs are contraindicated', Journal of Family Medicine and Primary Care. Wolters Kluwer--Medknow Publications, 9(2), p. 1199.

Mathew, M. G. (2020) 'Management of siblings with Glanzmann's thrombasthenia: A case report', Journal of Family Medicine and Primary Care. ncbi.nlm.nih. gov. Available at: https://www.ncbi.nlm.nih.gov/pmc/ articles/PMC7266179/.

Mathew, M. G. and Soni, A. J. (2019) 'Prevalence of three-rooted primary mandibular first molars in Karnataka (South Indian) population', International Journal of Pedodontic Rehabilitation. Medknow Publications and Media Pvt. Ltd., 4(1), p. 6.

Mathew, M. G., Soni, A. J. and Khan, M. M. (2020) 'A novel approach to regenerate bone loss in an adolescent using concentrated growth factors: Oneyear follow-up', Journal of Family. ncbi.nlm.nih.gov. Available at: https://www.ncbi.nlm.nih.gov/pmc/ articles/PMC7014901/.

Milgrom, P. et al. (1988) 'The prevalence and practice management consequences of dental fear in a major US city', Journal of the American Dental Association , 116(6), pp. 641-647.

Morita K. et al. (2001) '[Perioperative mortality and morbidity in 1999 with a special reference to age in 466 certified training hospitals of Japanese
Society of Anesthesiologists--report of Committee on Operating Room Safety of Japanese Society of Anesthesiologists]', Masui. The Japanese journal of anesthesiology, 50(8), pp. 909-921.

Nagaveni, N. B., Poornima, P. and Bajaj, M. (2019) 'Revascularization of a Nonvital, Immature Permanent Tooth Using Amniotic Membrane: A Novel Approach', Journal of Clinical .... ncbi.nlm.nih.gov. Available at: https://www.ncbi.nlm.nih.gov/pmc/articles/ PMC6749878/.

Nagaveni, N. B., Poornima, P. and Mathew, M. G. (2020) 'A Comparative Evaluation of Revascularization Done in Traumatized Immature, Necrotic Anterior Teeth with and without Platelet-rich Fibrin: A Case Report', Journal of Clinical .... ncbi.nlm.nih.gov. Available at: https:// www.ncbi.nlm.nih.gov/pmc/articles/PMC7299885/.

Nagaveni, N. B., Yadav, S. and Poornima, P. (2017) 'Volumetric evaluation of various obturation techniques in primary teeth using cone beam computed tomography-An in vitro study', Journal of Indian. jisppd.com. Available at: http://www.jisppd.com/article. asp?issn=0970-4388;year $=2017$; volume $=35 ;$ issue $=3 ;$ sp age $=244$; epage $=248$; aulast $=$ Nagaveni .

Nair, M. et al. (2018) 'Comparative evaluation of postoperative pain after pulpectomy with k-files, kedo-s files and mtwo files in deciduous molars -a randomized clinical trial', Brazilian Dental Science, 21(4), p. 411.

Neena, I. E. et al. (2017) 'Management of maxillary anterior supernumerary teeth', Astrocyte. astrocyte. in. Available at: http://www.astrocyte.in/article. asp?issn=2349-0977; year=2017; volume $=3$;issue $=4$;sp age $=231$; epage $=233$; aulast $=$ Neena .

Olsson, G. L. and Hallén, B. (1988) 'Cardiac arrest during anaesthesia. A computeraided study in 250543 anaesthetics', Acta anaesthesiologica Scandinavica, 32(8), pp. 653-664.

Ost, L. G. (1987) 'Age of onset in different phobias', Journal of abnormal psychology, 96(3), pp. 223-229.

Panchal, V., Gurunathan, D. and Shanmugaavel, A. K. (2017) 'Smartphone application as an aid in determination of caries risk and prevention: A pilot study', European journal of dentistry, 11(4), pp. 469474.

Panchal, V., Jeevanandan, G. and Subramanian, E. (2019) 'Comparison of instrumentation time and obturation quality between hand K-file, H-files, and rotary Kedo-S in root canal treatment of primary teeth: A randomized controlled trial', Journal of the Indian Society of Pedodontics and Preventive Dentistry, 37(1), pp. 75-79.

Panchal, V., Jeevanandan, G. and Subramanian, E. M. G. (2019) 'Comparison of post-operative pain after root canal instrumentation with hand K-files, H-files and rotary Kedo-S files in primary teeth: a randomised clinical trial', European archives of paediatric dentistry: official journal of the European Academy of Paediatric Dentistry, 20(5), pp. 467-472. 
Ramadurai, N. et al. (2019) 'Effectiveness of 2\% Articaine as an anesthetic agent in children: randomized controlled trial', Clinical oral investigations, 23(9), pp. 3543-3550.

Ramakrishnan, M., Dhanalakshmi, R. and Subramanian, E. M. G. (2019) 'Survival rate of different fixed posterior space maintainers used in Paediatric Dentistry - A systematic review', The Saudi dental journal, 31(2), pp. 165-172.

Rao, A., Sequeira, S. P. and Peter, S. (1999) 'Prevalence of dental caries among school children of Moodbidri', Journal of the Indian Society of Pedodontics and Preventive Dentistry, 17(2), pp. 45-48.

Ratnayake, N. and Ekanayake, L. (2005) 'Prevalence and impact of oral pain in 8-year-old children in Sri Lanka', International journal of paediatric dentistry / the British Paedodontic Society [and] the International Association of Dentistry for Children, 15(2), pp. 105-112.

Ravikumar, D. et al. (2018) 'DNA profiling of Streptococcus mutans in children with and without black tooth stains: A polymerase chain reaction analysis', Dental research journal, 15(5), p. 334.

Ravikumar, D. et al. (2019) 'Evaluation of McNamara's analysis in South Indian (Tamil Nadu) children between 8-12 years of age using lateral cephalograms', Journal of oral biology and craniofacial research, 9(2), pp. 193-197.

Ravikumar, D., Jeevanandan, G. and Subramanian, E. M. G. (2017) 'Evaluation of knowledge among general dentists in treatment of traumatic injuries in primary teeth: A cross-sectional questionnaire study', European journal of dentistry, 11(2), pp. 232-237.

Ravindra, V. et al. (2018) 'A comparative evaluation between dermatoglyphic patterns and different terminal planes in primary dentition', Journal of clinical and experimental dentistry, 10(12), pp. e1149-e1154.

Ravindra, V. et al. (2019) 'A comparative evaluation between cheiloscopic patterns and the permanent molar relationships to predict the future malocclusions', Journal of clinical and experimental dentistry, 11(6), pp. e553-e557.

Resine, S. T. (1985) 'Dental health and public policy: The social impact of disease', American journal of public health, 75(1), pp. 27-30.

Samuel, S. R., Acharya, S. and Rao, J. C. (2020) 'School Interventions-based Prevention of Early-Childhood Caries among 3-5-year-old children from very low socioeconomic status: Two-year randomized trial', Journal of public health dentistry, 80(1), pp. 51-60.

Schwartz, S. (1994) 'A one-year statistical analysis of dental emergencies in a pediatric hospital', Journal , 60(11), pp. 959-62, 966-8.

Subramanyam, D. et al. (2018) 'Comparative evaluation of salivary malondialdehyde levels as a marker of lipid peroxidation in early childhood caries', European journal of dentistry, 12(1), pp. 67-70.

Thomas, C. W. and Primosch, R. E. (2002) 'Changes in incremental weight and well-being of children with rampant caries following complete dental rehabilitation', Pediatric dentistry, 24(2), pp. 109-113.

Vellingiri, S. and Gurunathan, D. (2015) 'Assessment of parent's preference to general or local anesthesia for children undergoing dental treatment', World J Dent, 6(3), pp. 154-160.

Vignesh, R. et al. (2019) 'Management of Complicated Crown-Root Fracture by Extra-Oral Fragment Reattachment and Intentional Reimplantation with 2 Years Review', Contemporary clinical dentistry, 10(2), pp. 397-401.

Vishnu Prasad, S. et al. (2018) 'Report on oral health status and treatment needs of 5-15 years old children with sensory deficits in Chennai, India', Special care in dentistry: official publication of the American Association of Hospital Dentists, the Academy of Dentistry for the Handicapped, and the American Society for Geriatric Dentistry, 38(1), pp. 58-59. 